\title{
KARAKTERISTIK DAN HASIL UJI MARSHALL ASPAL TERMODIFIKASI DENGAN KARET ALAM TERDEPOLIMERISASI SEBAGAI ADITIF
}

\author{
Characteristic and Marshall Testing Result of Modified Asphalt with Depolymerized \\ Natural Rubber as Additive
}

\author{
Henry PRASTANTO, Adi CIFRIADI dan Arief RAMADHAN
}

Pusat Penelitian Karet

J1 Salak No. 1 Bogor 16151

Email : hprastanto@yahoo.com

Diterima : 17 November 2014 / Direvisi : 29 Januari 2015 / Disetujui : 7 Mei 2015

\begin{abstract}
Polymer modified asphalt is one kind of asphalt formula with the polymer addition to get better road pavement properties i.e. reduce the deformation of pavement, improve cracking resistance and the tackiness of aggregate. This research was conducted by using depolymerized natural rubber SIR 20 as additive of asphalt with the concentration of 3\%, 5\%, and $7 \% w / w$. Test result showed that base on penetration, softening point, flash point, and \% loss on heating it was found that the best concentration was 5\%. Data of Marshall test consisted of the stability, flow, index of retained strength, and Marshall Quotient were $1135.46 \mathrm{~kg}, 3.47 \mathrm{~mm}, 91.78 \%$, and $327.22 \mathrm{~kg} /$ $\mathrm{mm}$ respectively. That value had meet with polymer asphalt quality standard (SNI 06-248991) and it was better performance compared with asphalt without additive addition (control).
\end{abstract}

Keywords: Asphalt, additive, natural rubber, depolymerization, modification, Marshall test

\section{Abstrak}

Aspal termodifikasi polimer merupakan salah satu jenis formula aspal dengan penambahan polimer untuk mendapatkan sifat perkerasan jalan yang lebih baik, yaitu mengurangi deformasi pada perkerasan, meningkatkan ketahanan terhadap retak dan kelekatan pada agregat. Penelitian ini telah dilakukan dengan menggunakan karet alam SIR 20 terdepolimerisasi sebagai aditif pada aspal dengan konsentrasi 3\%, 5\%, dan 7\% b/b. Dari hasil pengujian penetrasi, titik lembek, titik nyala, dan \% kehilangan berat setelah pemanasan didapatkan konsentrasi terbaik, yaitu 5\%. Data hasil uji Marshall yang terdiri dari stabilitas, pelelehan, stabilitas sisa setelah perendaman, dan hasil bagi Marshall berturutturut adalah $1135,46 \mathrm{~kg}, 3,47 \mathrm{~mm}, 91,78 \%$, dan $327,22 \mathrm{~kg} / \mathrm{mm}$. Nilai tersebut telah memenuhi persyaratan SNI untuk aspal polimer (SNI 062489-91) dan memiliki sifat yang lebih baik daripada aspal tanpa penambahan aditif (kontrol).

Kata kunci: Aspal, aditif aspal, karet alam, depolimerisasi, modifikasi karet alam, uji Marshall

\section{PENDAHULUAN}

Usaha peningkatan konsumsi karet perlu tetap dilakukan terlebih pada saat harga karet alam sedang rendah dalam dua tahun terakhir ini, antara lain dijadikan bahan campuran aspal. Kerusakan jalan aspal yang umum terjadi adalah adanya keretakan dan bergelombang. Keretakan menyebabkan air masuk ke dalam struktur jalan aspal sehingga jalan aspal mudah berlubang. Jalan aspal yang bergelombang disebabkan oleh adanya titik leleh aspal yang terlalu rendah sehingga aspal di jalan mudah meleleh terkena panas matahari.

Aspal polimer (plastomer dan elastomer) adalah aspal keras yang dimodifikasi dengan polimer. Aspal polimer terdiri atas 2 jenis, yaitu aspal plastomer dan elastomer. Contoh plastomer (plastik) antara lain polypropylene dan polyethylene, sedangkan elastomer antara lain aspal karet alam dan Styrene butadiene styrene atau disingkat SBS (SNI 6749:2008). Penggunaan polimer sintetis telah dilakukan untuk meningkatkan mutu aspal. Sayangnya bahan tersebut merupakan bahan impor, sehingga tidak dapat memberi nilai tambah bagi produk lokal dalam negeri dan sangat tergantung dari produsen luar negeri. Salah satu upaya untuk mendorong penggunaan 
produk lokal, dalam hal ini karet alam diantaranya adalah penggunaan karet alam sebagai aditif aspal untuk menghasilkan aspal polimer.

Peningkatan mutu aspal dengan penambahan karet alam dilakukan melalui proses pencampuran. Pencampuran kedua bahan ini, karet alam dan aspal, dapat meningkatkan kinerja aspal antara lain mengurangi deformasi pada perkerasan, meningkatkan ketahanan terhadap retak dan meningkatkan kelekatan aspal terhadap agregat (Suroso, 2007). Karet alam sebagai polimer alam berpotensi untuk digunakan sebagai aditif aspal pengganti polimer sintetis impor tersebut. Penelitian tentang penggunaan lateks pekat sebagai bahan aditif aspal sudah dilakukan diantaranya oleh Tuntiworawit et al (2005) beserta para peneliti dari Thailand, dan Suroso (2007). Tuntiworawit (2005) melakukan penelitian menggunakan lateks pekat high ammonia (HA) dengan kadar amoniak lebih dari 0,6\%. Kadar lateks pekat dalam aspal divariasikan dari 1\%-13\% terhadap total berat campuran aspal karet. Proses pencampuran dilakukan pada suhu $140-150^{\circ} \mathrm{C}$ dengan kecepatan pengaduk cukup tinggi yaitu $5000 \mathrm{rpm}$ selama 20-30 menit. Berdasarkan hasil pengujian maka dapat disimpulkan bahwa aspal karet dengan sifat yang optimum adalah aspal karet dengan kadar lateks pekat 9\%. Pada tahun 2007, Suroso telah membandingkan pemakaian lateks pekat dengan karet sintetis pada aspal. Konsentrasi lateks pekat dan karet sintesis yang digunakan adalah 3\% dan 5\% terhadap berat aspal. Pembuatan campuran aspal dan lateks pekat juga sudah diterbitkan petunjuk pembuatannya oleh Departemen Pekerjaan Umum (1999). Masalah yang dihadapi dalam pembuatan aspal karet dengan bahan aditif berupa lateks pekat adalah adanya buih dan pelepasan gas amoniak. Berdasarkan pengalaman operator di lapangan, kondisi ini bisa membahayakan bagi pekerja.

Penelitian tentang aditif aspal dengan menggunakan karet alam telah dilakukan, yaitu dengan menggunakan karet padat berupa karet Ribbed Smoked Sheet (RSS) dan Standard Indonesian Rubber 20 (SIR 20). Vichitcholchai et al (2012) dari Thailand telah melakukan penelitian aspal karet dengan menggunakan RSS. Karet RSS dilakukan perlakukan pelunakan terlebih dahulu dengan cara digiling pada suhu $70^{\circ} \mathrm{C}$ selama 30 menit sebelum dicampurkan ke dalam aspal pada suhu $150-170^{\circ} \mathrm{C}$ dan diaduk selama 2 jam. Konsentrasi yang terbaik adalah pada konsentrasi karet 6\% terhadap berat aspal. Pemakaian karet mentah yang berupa padatan, baik itu karet remah (SIR), RSS, krep, apabila langsung digunakan sebagai aditif aspal maka akan membutuhkan waktu pencampuran yang sangat lama atau membutuhkan suhu yang lebih tinggi sehingga kurang diminati. Pencampuran yang lama dan suhu yang lebih tinggi menyebabkan pemborosan energi dan memperbanyak penguapan bagian dari aspal yang akan menyebabkan kehilangan bahan yang cukup banyak. Salah satu cara untuk menyelesaikan permasalahan tersebut adalah dengan cara depolimerisasi karet alam.

Depolimerisasi adalah kebalikan dari polimerisasi, yaitu proses pemutusan rantai molekul polimer menjadi polimer dengan rantai molekul yang lebih pendek. Dalam proses pembuatan kompon karet dikenal istilah mastikasi, yaitu proses penggilingan karet alam dalam open mill yang tujuannya juga untuk memutuskan rantai molekul karet alam agar menjadi lebih lunak. Menurut Staudinger dalam Bateman (1963), mastikasi dapat menurunkan berat molekul karet hingga sepersepuluh dari berat molekul karet semula sekitar $10^{6}$. Penurunan berat molekul ini secara bersamaan disertai dengan penurunan viskositas karet, dan dengan penurunan viskositas ini diharapkan karet alam menjadi lebih mudah dicampurkan dengan aspal. Prastanto (2014) telah melakukan penelitian dengan menggunakan karet SIR 20 sebagai aditif aspal. SIR 20 didepolimerisasi dengan perlakuan penggilingan, kemudian ditambahkan peptizer pada suhu $60^{\circ} \mathrm{C}$ dengan waktu divariasikan. Karet kemudian dicampurkan ke dalam aspal pada suhu $160^{\circ} \mathrm{C}$ dengan kadar karet dalam aspal juga divariasikan. Hasil terbaik sesuai dengan mutu aspal polimer adalah dengan kadar karet 5\% terhadap berat aspal.

Penelitian ini bertujuan untuk melakukan pengujian lebih lanjut dari hasil penelitian Prastanto (2014). Adapun pengujian tersebut adalah pengujian 
stabilitas Marshall dan titik lembek aspal karet yang dibuat dari karet hasil depolimerisasi yang sudah disimpan selama sekitar 1 bulan.

\section{BAHAN DAN METODE}

Penelitian ini dilakukan pada tahun 2010 di Pusat Penelitian Karet. Bahan utama yang digunakan dalam penelitian ini adalah karet alam berupa karet remah (SIR 20), peptizerdi-(o-bezamidephenyl) disulfide, hidroksilamin netral sulfat (HNS), dan aspal pen 60 . Sedangkan peralatan utama untuk depolimerisasi mekanis adalah open mill dengan kapasitas $1 \mathrm{~kg}$. Untuk proses pencampuran aspal dan karet digunakan kompor pemanas listrik, thermostat dan mixer.

Penelitian dilakukan dalam dalam tiga tahapan, yaitu: depolimerisasi karet alam secara mekanis dan kimiawi, pencampuran karet hasil alam terdepolimerisasi dengan aspal dan pengujian aspal karet hasil pencampuran. Untuk mengetahui pengaruh penyimpanan terhadap viskositas Mooney, waktu pencampuran dan sifat aspal karetnya, maka sampel karet hasil depolimerisasi tersebut disimpan selama 1 bulan

Depolimerisasi karet alam secara mekanis dan kimiawi dilakukan pada suhu sekitar $60^{\circ} \mathrm{C}$, dengan menggunakan penggilingan karet dalam open mill bersamaan dengan peptizer $2 \%$ terhadap karet untuk mempercepat pemutusan rantai molekul karet. Lama penggilingan ditentukan berdasarkan hasil terbaik penelitian sebelumnya, yaitu selama 24 menit dan pada akhir penggilingan ditambahkan HNS sebanyak $1 \%$ untuk mencegah adanya kenaikan viskositas selama penyimpanan.

Karet hasil penggilingan dicampurkan ke dalam aspal panas pada suhu $160^{\circ} \mathrm{C}$. Konsentrasi karet dalam aspal divariasikan sebesar 3\%, 5\% dan $7 \%$ terhadap berat aspal dan sebagai pembanding digunakan aspal murni. Sampel kemudian didinginkan dan kemudian diuji titik lembek, penetrasi, titik nyala, dan kehilangan beratnya di Laboratorium Balai Besar Pelaksanaan Jalan Nasional IV Cikampek. Konsentrasi terbaik dari tahap ini, selanjutnya digunakan untuk pembuatan sampel untuk uji Marshall.

Untuk mengetahui pengaruh pe nyim pan a n, s a m pel karet terdepolimerisasi yang sudah disimpan selama 1 bulan, diukur viskositas Mooney karet dan waktu pencampuran dalam aspal. Hasil campuran aspal dan karet kemudian diuji titik lembek dan penetrasinya.

\section{HASIL DAN PEMBAHASAN}

Depolimerisasi karet alam secara mekanis dapat menurunkan berat molekul karet alam yang ditandai dengan turunnya viskositas Mooney karet alam. Viskositas Mooney karet alam yang digunakan dalam penelitian pada saat sebelum dilakukan depolimerisasi adalah sebesar 58,7 $\mathrm{ML}(1+4) 100^{\circ} \mathrm{C}$. Depolimerisasi secara mekanis dan kimiawi dilakukan dengan cara karet alam digiling dalam open mill atau biasa disebut mastikasi dengan menambahkan di-(o-bezamidephenyl) disulfide sebagai bahan pemutus rantai molekul karet (peptizer) selama 24 menit, dapat menurunkan viskositas Mooney karet alam menjadi $6,7 \mathrm{ML}(1+4) 100^{\circ} \mathrm{C}$. Proses depolimerisasi ini telah menghasilkan penurunan viskositas Mooney karet alam yang efektif sebesar $88,5 \%$.

Hasil penelitian awal menunjukkan bahwa karet alam yang telah didepolimerisasi dengan viskositas Mooney sebesar $6,7 \mathrm{ML}(1+4) 100^{\circ} \mathrm{C}$ apabila digunakan sebagai aditif aspal, memiliki waktu pencampuran aspal-karet yang tercepat dibandingkan dengan sampel karet lain yang memiliki viskositas Mooney yang lebih besar. Waktu pencampuran karet alam ke dalam aspal tanpa depolimerisasi adalah 660 menit, sedangkan karet alam hasil depolimerisasi tersebut membutuhkan waktu pencampuran 13 kali lebih cepat yakni hanya selama 50 menit. Dengan mempertimbangkan kemudahan dalam pencampuran, maka karet alam dengan depolimerisasi selama 24 menit ini secara ekonomis lebih memungkinkan untuk digunakan sebagai aditif aspal.

Hasil pengujian aspal yang telah didepolimerisasi selama 24 menit atau karet alam dengan viskositas Mooney sebesar 6,7 
$\mathrm{ML}(1+4) 100^{\circ} \mathrm{C}$, juga menunjukkan hasil yang baik. Nilai titik lembek dan penetrasi secara umum sudah memenuhi persyaratan aspal polimer. Oleh karena itu dilakukan pengujian yang lebih lengkap dalam skala yang lebih besar. Hasil pengujian aspal dengan konsentrasi karet sebesar 3\%, 5\% dan $7 \%$ terhadap aspal disajikan dalam Tabel 1 berikut.

Titik nyala perlu diketahui untuk memperkirakan temperatur maksimum pemanasan aspal hingga aspal tidak terbakar. Titik nyala adalah suhu pada saat terlihat nyala singkat pada satu titik diatas permukaan aspal. Kehilangan berat dilakukan untuk mengetahui pengurangan berat akibat penguapan bahan-bahan yang mudah menguap dalam aspal karena pemanasan. Hasil pengujian menunjukkan bahwa kadar karet sebesar 5\% dan 7\% telah memenuhi kriteria untuk persyaratan penetrasi, titik lembek, titik nyala dan kehilangan berat. Sedangkan aspal karet dengan kadar karet 3\%, untuk penetrasi dan titik lembek belum memenuhi persyaratan aspal polimer.

Tahap akhir dalam proses pengujian aspal polimer yang merepresentasikan uji skala lapang adalah uji Marshall. Uji ini telah lengkap menggunakan aspal polimer, aditif karet serta agregat yang dilapisi oleh aspal sehingga dapat mewakili uji skala lapang. Pengujian ini terdiri dari uji stabilitas, pelelehan, stabilitas sisa setelah perendaman, dan hasil bagi Marshall (MQ). Uji stabilitas merupakan kemampuan dari suatu campuran beraspal untuk menerima beban lalu lintas tanpa mengalami perubahan bentuk, seperti alur, retak, dan sebagainya. Sedangkan uji pelelehan adalah suatu perubahan bentuk plastis suatu campuran beraspal yang disebabkan oleh beban. Dalam campuran beraspal, nilai pelelehan dipengaruhi oleh kadar aspal, temperatur, dan viskositas. Stabilitas sisa setelah perendaman adalah pengujian untuk mengetahui ketahanan terhadap pengaruh suhu dan air. Hasil bagi Marshall atau Marshall Quotien (MQ) adalah hasil bagi antara stabilitas dengan pelelehan yang merupakan ukuran tingkat keretakan suatu campuran. Semakin besar nilai MQ, maka campuran akan semakin kaku dan kemungkinan terjadinya deformasi sangat kecil.

Dalam pengujian Marshall ini dipilih sampel dengan konsentrasi karet 5\%, karena pada pengujian sifat aspal polimer sudah memenuhi persyaratan dengan konsentrasi yang tidak terlalu besar. Hasil pengujian Marshall yang mewakili uji lapang aditif aspal disajikan pada Tabel 2.

Tabel 1. Hasil pengujian campuran aspal karet alam

Table 1. Testing result of natural rubberized asphalt mixture

\begin{tabular}{|c|c|c|c|c|c|c|c|}
\hline \multirow[t]{2}{*}{$\begin{array}{l}\text { Pengujian } \\
\text { Testing }\end{array}$} & \multirow[t]{2}{*}{$\begin{array}{l}\text { Metode } \\
\text { uji } \\
\text { Methods }\end{array}$} & \multicolumn{2}{|c|}{$\begin{array}{l}\text { Persyaratan } \\
\text { aspal polimer } \\
\text { Requirement }\end{array}$} & \multirow{2}{*}{$\begin{array}{l}\text { Aspal } \\
\text { kontrol } \\
\text { Asphalt } \\
\text { control }\end{array}$} & \multicolumn{3}{|c|}{$\begin{array}{c}\text { Aspal karet } \\
\text { Rubberized asphalt } \\
(\%)\end{array}$} \\
\hline & & Min & Maks & & 3 & 5 & 7 \\
\hline $\begin{array}{l}\text { Penetrasi; } 25^{\circ} \mathrm{C}, 100 \mathrm{~g} ; \\
5 \text { detik; } 0,1 \mathrm{~mm} \\
\text { Penetration }\end{array}$ & $\begin{array}{l}\text { SNI 06- } \\
2456- \\
1991\end{array}$ & 50 & 75 & 55 & 50 & 51 & 50,5 \\
\hline $\begin{array}{l}\text { Titik lembek, }{ }^{\circ} \mathrm{C} \\
\text { Softening point }\end{array}$ & $\begin{array}{l}\text { SNI 06- } \\
2434- \\
1991\end{array}$ & 54 & - & 51 & 53 & 54 & 55,5 \\
\hline $\begin{array}{l}\text { Titik nyala, }{ }^{\circ} \mathrm{C} \\
\text { Flash point }\end{array}$ & $\begin{array}{c}\text { SNI 06- } \\
2433- \\
1991\end{array}$ & 232 & - & 303 & 311 & 318 & 312 \\
\hline $\begin{array}{l}\text { Kehilangan berat } \\
\text { setelah pemanasan, \% } \\
\text { Loss on heating, } \%\end{array}$ & $\begin{array}{l}\text { SNI 06- } \\
2440- \\
1991\end{array}$ & - & 1,0 & 0,09 & 0,157 & 0,159 & 0,159 \\
\hline
\end{tabular}


Tabel 2. Hasil pengujian Marshall campuran aspal karet alam

Table 2. Marshall testing result of natural rubberized asphalt

\begin{tabular}{|c|c|c|c|c|c|}
\hline \multirow[t]{2}{*}{$\begin{array}{l}\text { Jenis pengujian } \\
\text { Testing }\end{array}$} & \multirow[t]{2}{*}{$\begin{array}{l}\text { Metode uji } \\
\text { Test Method }\end{array}$} & \multicolumn{2}{|c|}{$\begin{array}{l}\text { Persyaratan } \\
\text { aspal } \\
\text { Specification }\end{array}$} & \multirow{2}{*}{$\begin{array}{c}\text { Aspal } \\
\text { kontrol } \\
\text { Asphalt } \\
\text { control }\end{array}$} & \multirow{2}{*}{$\begin{array}{c}\text { Aspal karet } \\
5 \% \\
\text { Rubberized } \\
\text { asphalt 5\% }\end{array}$} \\
\hline & & Min & Maks & & \\
\hline $\begin{array}{l}\text { Stabilitas, } \mathrm{kg} \\
\text { Stability, } \mathrm{kg}\end{array}$ & SNI 06-2489-91 & 750 & - & 1045,74 & 1135,46 \\
\hline $\begin{array}{l}\text { Pelelehan, mm } \\
\text { Flow, } \mathrm{mm}\end{array}$ & SNI 06-2489-91 & 2 & 4 & 3,37 & 3,47 \\
\hline $\begin{array}{l}\text { Stabilitas sisa setelah perendaman, } \% \\
\text { Index of retained strength, } \%\end{array}$ & SNI 06-2489-91 & 75 & - & 81,53 & 91,78 \\
\hline $\begin{array}{l}\text { Hasil bagi Marshall, } \mathrm{kg} / \mathrm{mm} \\
\text { Marshall Quotient, } \mathrm{kg} / \mathrm{mm}\end{array}$ & SNI 06-2489-91 & - & - & 310,31 & 327,22 \\
\hline
\end{tabular}

Dari data pengujian Marshall di atas terlihat bahwa aspal beraditif karet ini telah memenuhi persyaratan SNI dan memiliki sifat yang lebih baik daripada aspal tanpa aditif. Data tersebut mencerminkan bahwa aspal beraditif karet ini lebih tahan terhadap timbulnya retak, alur, perubahan bentuk dan lebih rekat terhadap agregat.

Karet alam secara umum mengalami pengerasan selama penyimpanan yang ditunjukkan dari perubahan viskositas dan viskositas karet alam akan umumnya bertambah selama proses penyimpanan atau dikenal dengan istilah storage hardening (Solichin, 2000). Hal ini dikarenakan oleh adanya reaksi gugusgugus kimia (gugus aldehid) antar rantai molekul polimer karet sehingga berat molekul karet rata-rata bertambah dikarenakan adanya perpanjangan rantai molekul karet (sekhar, 1961). Penambahan HNS dimaksudkan untuk mencegah adanya reaksi perpanjangan rantai molekul karet sehingga viskositas karet hasil depolimerisasi dapat dipertahankan. Pengaruh waktu penyimpanan selama sekitar satu bulan terhadap viskositas karet disajikan dalam Tabel 3. Hasil uji viskositas karet hasil depolimerisasi ternyata masih mengalami sedikit penurunan viskositas, yang seharusnya tidak terjadi perubahan nilai viskositas. Hal ini bisa disebabkan oleh adanya reaksi lanjutan depolimerisasi karet alam selama penyimpanan yang mengakibatkan pemutusan rantai molekul karet oleh bahan peptizer (di-(obezamidephenyl) disulfide)masih terjadi. Akibatnya viskositas karet menjadi turun karena proses pembentukan radikal bebas dari reaksi depolimerisasi tersebut. Disamping itu juga disebabkan belum tepatnya dosis HNS yang ditambahkan dan belum adanya bahan yang berfungsi untuk menghentikan proses depolimerisasi secara kimia (terminator).

Tabel 3. Pengaruh penyimpanan terhadap viskositas karet alam hasil depolimerisasi Table 3. The effect of storage to depolymerized natural rubber viscosity

\begin{tabular}{|c|c|c|c|c|}
\hline \multirow[t]{2}{*}{ No. } & \multirow{2}{*}{$\begin{array}{l}\text { Waktu giling SIR } 20 \\
\text { (menit) } \\
\text { Milling time } \\
\text { (minutes) }\end{array}$} & \multicolumn{2}{|c|}{$\begin{array}{l}\text { Viskositas Mooney } \\
\left.\left(\mathrm{ML}\left(1^{-}+4^{-}\right) 100\right)^{\circ} \mathrm{C}\right) \\
\text { Visc. Mooney value }\end{array}$} & \multirow[t]{2}{*}{$\begin{array}{l}\text { Rataan } \\
\text { Average }\end{array}$} \\
\hline & & 1 & 2 & \\
\hline 1 & $\begin{array}{l}24 \text { menit } \\
24 \text { minutes }\end{array}$ & 6,7 & 6,7 & 6,7 \\
\hline 2 & $\begin{array}{l}24 \text { menit (umur simpan } 33 \text { hari) } \\
24 \text { minutes (after } 33 \text { days storage) }\end{array}$ & 5,0 & 5,0 & 5,0 \\
\hline
\end{tabular}


Sifat karet hasil depolimerisasi yang sudah disimpan terlebih dahulu selama sekitar satu bulan, pada saat dicampur dengan aspal memiliki sedikit perbedaan apabila dibandingkan dengan karet depolimerisasi sebelum penyimpanan. Perbedaan ini terlihat pada waktu pencampuran, titik lembek maupun penetrasinya. Dengan penyimpanan karet terdepolimerisasi selama sekitar satu bulan, waktu pencampuran karet terdepolimerisasi ke dalam aspal menjadi lebih lama $\mathrm{d}$ i ba ndingkan d engan karet terdepolimerisasi tanpa penyimpanan, seperti yang disajikan dalam Gambar 1. Hal ini disebabkan karet terdepolimerisasi selama penyimpanan kemungkinan beberapa rantai molekul karet mengalami proses gelling akibat interaksi antar rantai molekul karet tersebut. Perbedaan ini tidaklah terlalu besar yaitu hanya sekitar 5 hingga 7 menit. Selisih ini tidaklah terlalu berbeda dikarenakan pengujian tingkat kelarutan yang dilakukan hanya bersifat visual saja.

Titik lembek aspal dengan perlakuan penyimpanan pada aditif karet terdepolimerisasi, mengalami sedikit penurunan hal ini dikarenakan viskositas karet setelah disimpan mengalami penurunan. Penurunan viskositas ini disebabkan oleh adanya reaksi lanjutan radikal bebas untuk mencapai kondisi yang stabil atau penghentian reaksi radikal oleh oksigen bebas dilingkungan setelah proses depolimerisasi. Penurunan titik lembek berkisar antara 1 hingga $2{ }^{\circ} \mathrm{C}$ seperti yang diperlihatkan pada Gambar 2. Aspal yang mengandung karet yang sudah disimpan dengan kadar karet 5\% hanya memiliki titik lembek $53^{\circ} \mathrm{C}$ saja. Sehingga sampel ini menjadi tidak memenuhi persyaratan mutu aspal polimer. Berdasarkan hasil pengujian ini maka karet yang sudah didepolimerisasi sebaiknya segera digunakan sebagai aditif aspal. Apabila kondisi di lapangan menyebabkan karet harus disimpan terlebih dahulu, maka perlu dilakukan penelitian lebih lanjut terkait dengan konsentrasi HNS yang optimum, agar karet yang sudah mengalami depolimerisasi tidak mengalami perubahan yang berarti selama penyimpanan.

Titik lembek aspal dengan perlakuan penyimpanan pada aditif karet terdepolimerisasi sedikit mengalami penurunan yang artinya aspal menjadi lebih keras. Penurunan penetrasi aspal berkisar antara 1,5 sampai $6,5 \mathrm{dmm}$ seperti yang diperlihatkan pada Gambar 3. Penambahan kekerasan aspal ini bila dibandingkan dengan aspal modifikasi dengan karet terdepolimerisasi yang belum disimpan diduga kuat karena pemanasan yang lebih lama saat pencampuran karet ke dalam aspal. Penambahan waktu selama 5 menit untuk kadar 3\% dan 5\% menurunkan penetrasi sampel sebesar 1,5 dmm. Sedangkan penambahan waktu pencampuran selama 15 menit pada sampel dengan kadar karet $7 \%$ menurunkan penetrasi sebanyak 6,5 dmm. Pemanasan yang lebih lama akan menyebabkan penguapan pada bahan yang mudah menguap pada aspal. Bahan yang mudah menguap tentunya memiliki kekerasan yang lebih rendah bila dibandingkan dengan bahan yang tidak mudah menguap. Semakin banyaknya penguapan bahan yang lebih lunak inilah yang menyebabkan aspal menjadi lebih keras.

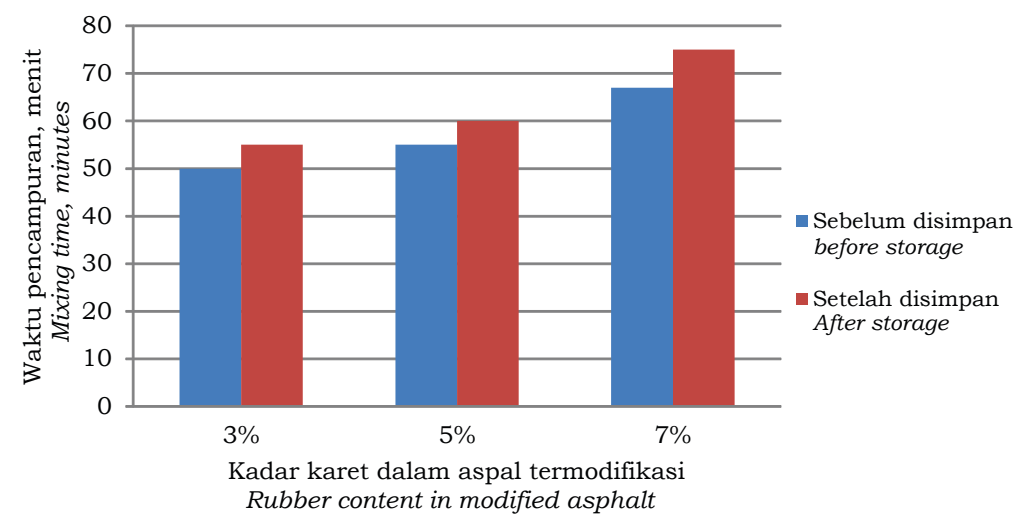

Gambar 1. Pengaruh penyimpanan terhadap waktu pencampuran karet ke dalam aspal

Figure 1. The effect of storage to mixing time of rubber and asphalt 


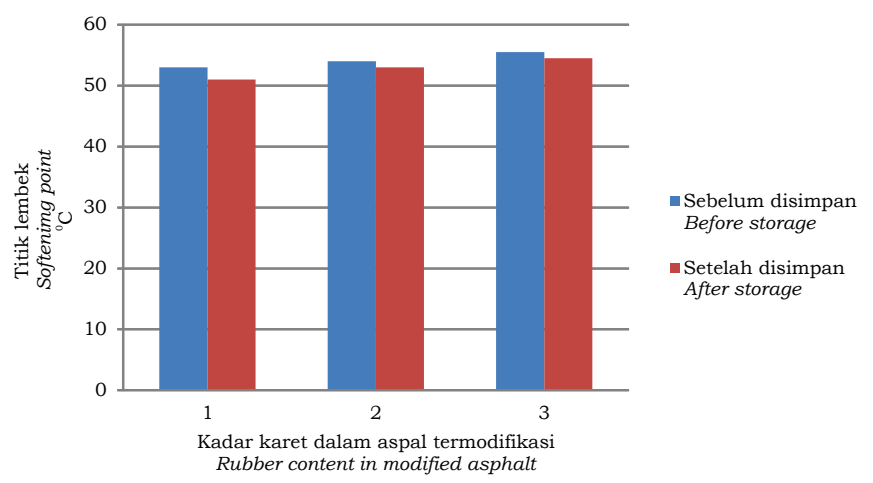

Gambar 2. Efek penyimpanan terhadap titik lembek aspal modifikasi Figure 2. The effect of storage to softening of modified asphalt

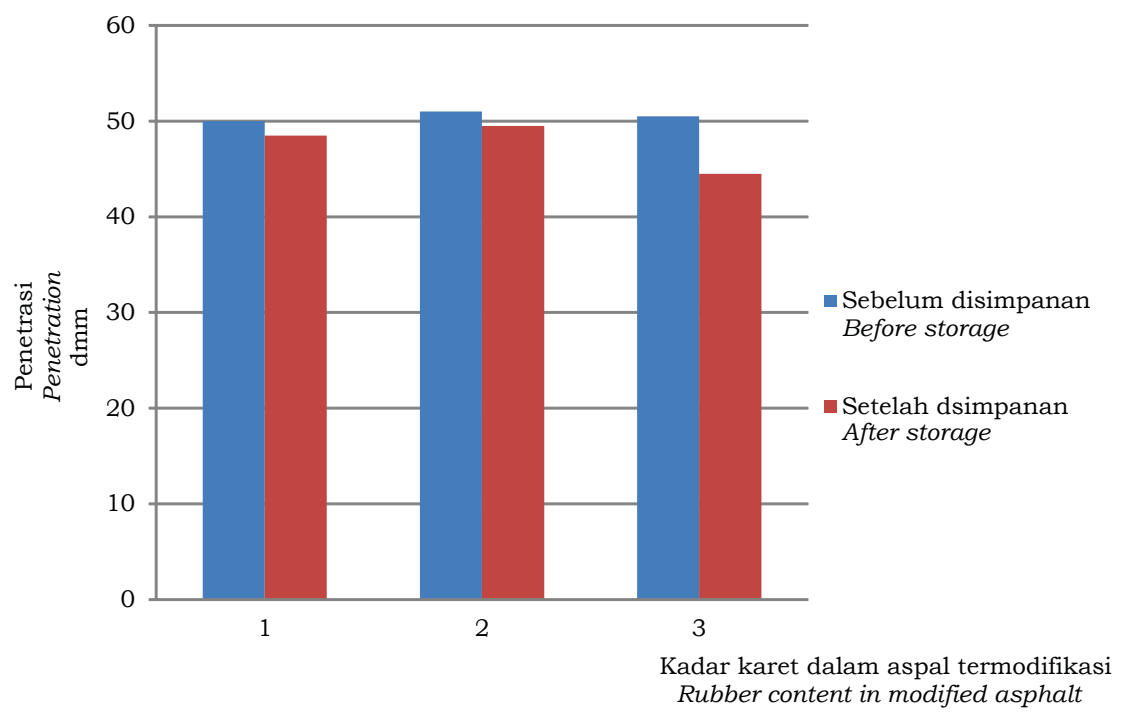

Gambar 3. Efek penyimpanan karet terdepolimerisasi terhadap penetrasi aspal Figure 3. The effect of depolymerized rubber storage to penetration of asphalt.

Berdasarkan hasil penelitian di atas, didapatkan waktu penggilingan, konsentrasi zat aditif karet padat dalam aspal, dan waktu pencampuran aditif karet-aspal yang optimal (24 menit, 5\% dan 55 menit). Oleh karena itu, dapat disusun formula aditif karet untuk aspal, formula aspal karet yang disajikan dalam Tabel 5 dan Tabel 6.

\section{KESIMPULAN DAN SARAN}

Aspal yang dimodifikasi dengan penambahan aditif karet alam terdepolimerisasi memiliki waktu pencampuran yang lebih cepat daripada aditif karet alam biasa. Selain itu, nilai titik lembek, penetrasi, titik nyala dan \% kehilangan berat dari aspal termodifikasi karet alam terdepolimerisasi masih memenuhi persyaratan aspal polimer. Penerapan teknologi ini dapat dilakukan dilapangan sesuai dengan hasil Uji Marshall memperlihatkan pada aspal termodifikasi dengan konsentrasi karet alam sebesar 5\% dari aspal, telah memenuhi persyaratan SNI dan memiliki sifat yang lebih baik dari pada aspal tanpa aditif, dengan nilai stabilitas $1135,46 \mathrm{Kg}$, pelelehan $3,47 \mathrm{~mm}$, stabilitas sisa setelah perendaman $91,78 \%$ dan hasil bagi Marshall 327,22 kg/mm. Teknologi ini perlu segera diaplikasikan dalam skala uji coba langsung di lapangan dengan bekerjasama dengan pihak operator pengaspalan jalan raya yang terkait. 
Tabel 5. Formula untuk depolimerisasi karet alam Table 5. Formula for natural rubber depolymerization

\begin{tabular}{|c|c|c|}
\hline No & $\begin{array}{l}\text { Bahan } \\
\text { Material }\end{array}$ & $\begin{array}{c}\text { Jumlah } \\
\text { Weight }\end{array}$ \\
\hline 1 & $\begin{array}{l}\text { Karet (SIR 20) } \\
\text { Rubber (SIR 20) }\end{array}$ & 100 gram \\
\hline 2 & Peptizer & 0,2 gram \\
\hline 3 & HNS (Hydroxylamine neutral sulfate) & 1 gram \\
\hline
\end{tabular}

Tabel 6. Formula aspal beraditif karet Table 6. Formula of Rubberized Asphalt

\begin{tabular}{clc}
\hline No & \multicolumn{1}{c}{$\begin{array}{c}\text { Bahan } \\
\text { Material }\end{array}$} & $\begin{array}{c}\text { Jumlah } \\
\text { Weight }\end{array}$ \\
\hline 1 & $\begin{array}{l}\text { Aspal } \\
\text { Asphalt }\end{array}$ & 100 gram \\
2 & $\begin{array}{l}\text { Karet (SIR 20 Terdepolimerisasi) } \\
\text { Rubber (Depolimerized SIR 20) }\end{array}$ & 5 gram \\
\hline
\end{tabular}

\section{DAFTAR PUSTAKA}

Badan Standarisasi Nasional. 1990. SNI061903-1990, Standar Nasional Indonesia, Standar Indonesian Rubber (SIR). BSN, Jakarta.

Badan Standarisasi Nasional. 1991. SNI 062434-1991. Standar Nasional Indonesia, Metode Pengujian Titik Lembek Aspal dan Ter. BSN, Jakarta.

Badan Standarisasi Nasional. 2008. SNI 6749:2008, Standar Nasional Indonesia Spesifikasi Lapis Tipis Aspal Pasir (Latasir). BSN, Jakarta

Bateman, L. 1963 The Chemistry and Physics of Rubber-Like Substances, Studies of The Natural Rubber Producer's Research Association. Mac Laren \& Sons Ltd, London.

Departemen Pekerjaan Umum. 1999. "Pedoman Penggunaan Aspal Karet dalam Campuran Beraspal Secara Panas No 010/T/BM/1999". Yayasan Penerbit Pekerjaan Umum, Jakarta.

Prastanto, H. 2014. Depolimerisasi Karet Alam Secara Mekanis untuk Bahan Aditif Aspal. Jurnal Penelitian Karet 32 (1) : 81-87.
Sekhar, B. C. 1961. Inhibition of Hardening In Natural Rubber. Rubber Chemistry and Technology 35 (4) : 889 - 895.

Solichin, M. 2000. Pengaruh Bahan Nonrubber Terhadap Oksidasi, Storage Hardening dan Sifat Vulkanisat Karet. Warta Perkaretan $19(1-3)$ : 63-71.

Suroso, T. W, 2007, Peningkatan Kinerja Campuran Beraspal dengan Karet Alam dan Karet Sintetis, Jurnal JalanJembatan 24 (1) : 14-25.

Tuntiworawit. N., C. Phromsorm, and D. Lavansiri. 2005. The Modification of Asphalt with Natural Rubber Latex, Proceedings of the Eastern Asia Society for Transportation Studies. 5 : 679 694.

Vichitcholchai, N., J. Panmai, and N. NaRanong. 2012. Modification of Asphalt Cement by Natural Rubber for Pavement Construction, Rubber Thai Journal 1 : 32-39. 